\title{
SECONd Conversazione.
}

May 2, 1854.

The second and last Conversazione of the season took place in the Society's rooms on the evening of May 2.

A number of interesting articles were exhibited:-including a series of Prints, representing the Triumphal Procession on the occasion of the Meeting of the Emperor Charles V. and Pope Clement VII. at Bologna, in the year 1529; and of the Funeral Procession of Charles Gustavus, King of Sweden, in 1660: contributed by JAMES DRUMmond, R.S.A.

A full-length Portrait of King James VI., said to be painted by George Jamesone : contributed by Barrox Grahame of Morphie, Esq.

An Original Portrait of the Marquis of Montrose : from the Collection of his Grace the Duke of Montrose; to be engraved for the Life of Montrose, by Mark NAPIER, Esq.

Eight Drawings of Trinity College Hospital, taken before the demolition of the building in 1845 , by Mr William Douglas, en- 
graver, Edinburgh : contributed by the Rev. JoHN SIME, F.S.A. Scot., late chaplain of the Hospital.

Portraits believed to be of King James VII. ; of Prince Charles Edward Stuart and his Wife Clementina: contributed by H. C. Maclaurin, Esq., F.S.A. Scot:

Antique Box which belonged to the Cadies of Edinburgh, or fraternity of persons who run errands, with their Seal of Cause granted in 1771 : contributed by J. Ballanitine, Esq., F.S.A. Scot.

Iron Money Box, of the Ancient and Royal Fraternity of Chapmen of the Three Lothians, incorporated 1530, containing Three Old Charters; and the Brass Measure used by the Fraternity : contributed by Mr JAMEs Tod, Engraver.

Curious Old Time-Piece: contributed by Hugh James Rollo, Esq., W.S.

Reliquiary Cross, inlaid with mother-of-pearl: contributed by Horatio M'Culloch, Esq., R.S.A., F.S.A. Scot. This fine specimen of inlaid work was brought from Italy, by William B. Johnston, Esq., R.S.A., and F.S.A. Scot.

\section{May 22, 1854.}

ARCHIBALD T. BOYLE, Esq., Advocate, in the Chair.

Amongst the Donations laid on the table were-

Stukeley's Antiquities of Stonehenge and Abury, 2 vols. in 1, folio; Genealogy of the House of Drummond, 4to, privately printed; Rapin, Histoire d'Angleterre, 12 vols. 4to; Æn. Vici Imagines Cæsarum, 1553, 4to, \&c. \&c. : by David LaING, Esq., F.S.A. Scot.

Antique Wheel Lock Pistol, of the Cinque Cento period, formerly in the possession of the late Sir William Allan, Pres. R.S.A. : by William Douglas, Esq., R.S.A. 
Large Iron Spur, found 13 feet below the surface in digging a Drain in Bishop's Close, High Street: by J. T. Gibson CraIG, Esq., F.S.A. Scot.

Sketch of the History and Condition of the Parochial Records in Scotland; by George Seton, Esq., F.S.A. Scot.: by the Author.

View of the History and Coinage of the Parthians; by Jorn Lindsay, Esq., Cor. Mem. S.A. Scot, Cork: by the Author.

Transactions of the Royal Irish Academy, Vol. 22: by the Academy.

Transactions of the Kilkenny Archrological Society, Vol. 2, Part 1: by the Society.

Lange, Diplomatarium Norvegicum, Vol. 4; Olaf den Helliges Saga, ved Snorre Sturlasson; Olaf Tryggvesöns Saga, ved Odd Munk: by the Royal University of Christiania, Norway.

Mémoires de la Société des Antiquairés de Normandie, Tomes $18,19,20$ : by the Societry of Antiquaries of Normandy.

Sur les Fouilles de Vieux, par M. A. Charma, Caen; Académie des Sciences, Arts, et Belles-Lettres, de Caen : Discours d'Ouverture, prononcé par M. A. Charma, Presidént: by the Author.

The first Communication read was entitled- 